\title{
Easy and Unbiased Determination of the Maxillary Sinus Volume
}

\author{
Fácil Determinación y sin Sesgo del Volumen del Seno Maxilar
}

"Cesar Coronado; ** Oscar Arriagada \&** Iván Suazo Galdames

CORONADO, C.; ARRIAGADA, O. \& SUAZO, G. I. Easy and unbiased determination of the maxillary sinus volume. Int. J. Morphol., 29(4):1375-1378, 2011.

SUMMARY: Determining the volume of the maxillary sinus is necessary in certain procedures. We present a simple method for estimating the volume of the maxillary sinus from groups 3, 5 and 9 coronal CT scan using the Cavalieri method combined with systematic sampling and evaluated randomized images. We used 10 dry skulls submitted to the TC. The actual volume was determined using silicone adapted to the maxillary sinus cavity. The estimated volume showed a high correlation with real volume, with no differences between groups. We concluded that it is possible to estimate without bias and with high accuracy the volume of the maxillary sinus from a minimum of $3 \mathrm{CT}$ images obtained through randomized systematic sampling and the proposed method.

KEY WORDS: Cavalieri's principle; Volume; Computed tomography; Maxillary sinus.

\section{INTRODUCTION}

The maxillary sinus are irregular cavities that develop within the maxillary bone thickness. Its volume is determined by a number of factors as age, remaining dental pieces, alveolar bone height, etc. (Cho et al. 2010), in reference to the presence of chronic sinus pathology, Debb et al. (2011) reported a decrease of sinus volume in subjects with chronic rhinosinusitis associated with the increase in thickness of the mucosa and cortical bone.

Prompt evaluation of the maxillary sinus volume can be useful in procedures of sinus floor elevation in placement of implants (Kuhl et al., 2010) or to establish the optimal volume of implant in this procedure (Gray et al., 2000); it is also useful to determine the percentage of pneumatization in this cavity (Park et al., 2011).

Determining dimensions of the maxillary sinus is namely realized through lineal and volumetric analysis of images obtained in the TC. These procedures require the use of specialized software. Exactness of volumes determined by means of these instruments is also influenced by anatomy of the maxillary sinus and decreases when it is exceedingly irregular (Perella et al., 2003; 2004; Song et al. 2009; Debb et al.), consequently, the use of methods to calculate the volume in such irregular cavities becomes necessary.
In this work we present a simple method to estimate the volume of the maxillary sinus using the Cavalieri principle that can be applied by the clinician from the screen of a conventional computer.

\section{MATERIAL AND METHOD}

We analyzed 10 dry skulls of adult subjects obtained from the Morphology Laboratory of the Universidad de Talca, which were located in anatomical position inside Styrofoam containers and moved to a Toshiba Asteion 4 MultiSlice CT scanner. A series of $1 \mathrm{~mm}$ thickness TC images were realized. Images were obtained by scanner (volume acquisition) and observed on computer annexed to the equipment where they were recorded on compact disc for subsequent analysis. Images were observed on a portable computer with Windows for Windows XP version Service Pack 2, screen resolution of $1280 \mathrm{x} 800$; using a test system of transparent mesh separated at $5 \mathrm{~mm}$ from each other (Fig. 1).

Images containing some segment of the right or the left maxillary sinus were selected. To realize the estimate points found within anatomical surface pertaining to the maxillary sinus were counted and provided the segment

\footnotetext{
* Facultad de Odontología, Universidad San Sebastián sede Concepción, Chile

${ }^{* *}$ Universidad de Talca, Chile.
} 


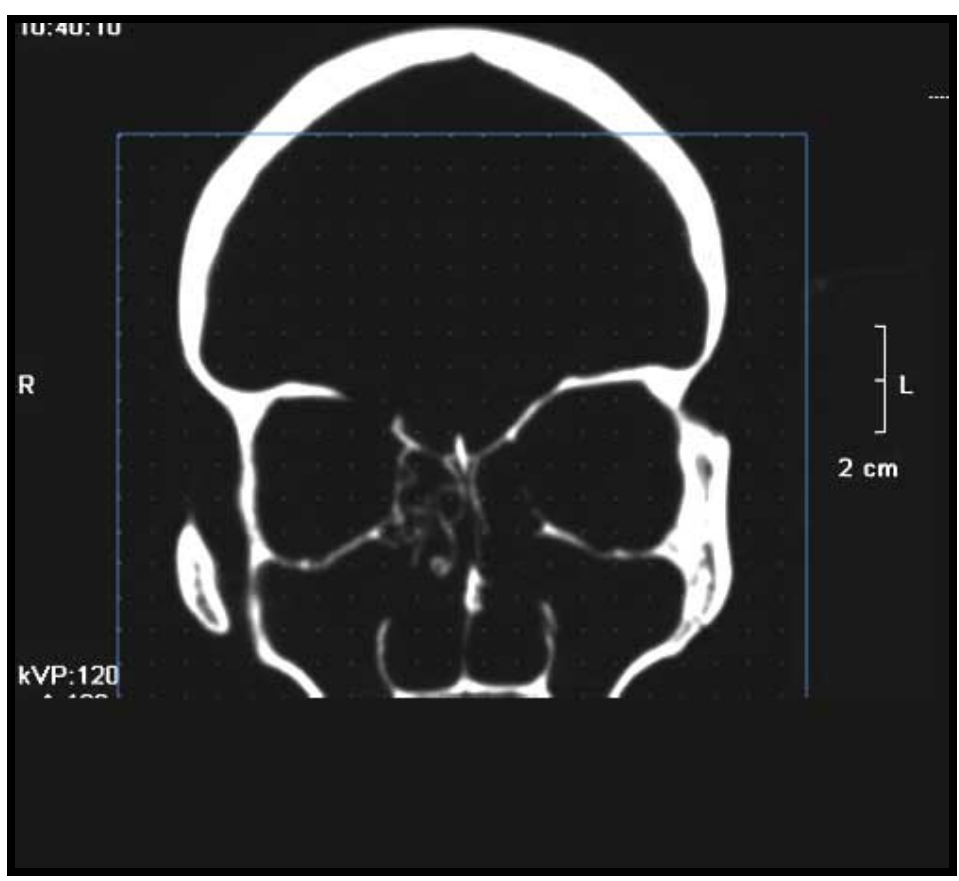

Fig. 1. Outline of TC image observed on the computer screen and superimposed, transparent mesh of points separated at $5 \mathrm{~mm}$ between each point.

estimated area. For the number of images to be analyzed, total images where maxillary sinus was observed were separated in groups randomly selecting the first image for analysis following sequence depending on the number of slices present in the groups. In order to calculate estimated volume, modified volume estimate formula for radiological images was used (Fig. 2).

$$
\mathrm{V}=\mathrm{g} \times \frac{[(\mathrm{UE}) \mathrm{x} \mathrm{d}]^{2}}{\mathrm{LE}} \times \Sigma \mathrm{P} \times \mathrm{CG}
$$

$\mathrm{g}=$ Breadth of consecutive section.

$\mathrm{UE}=$ Scale unit of image observed on computer.

$\mathrm{d}=$ Distance between points of the test mesh.

$\mathrm{LE}=$ Scale length measured on computer screen.

_P $=$ Sum of points counted in all images observed.

$\mathrm{CG}=$ Corresponds to the number of slices per group.

Three different analysis were carried out in which the number of slices per group varied. Constituting groups of 3,5 and 9 slices which, as the formula was applied allowed maxillary sinus volume estimate in each case.

Determination of the real volume (Gold Standard). Real maxillary sinus volume was obtained determining the volume for an impression, using for impression material heavy condensation silicone
(Polydimethylsiloxane) for dentistry use (Swiss Tec ${ }^{\circledR}$ putty). For the impression it was necessary to obtain a $2 \times 2 \mathrm{~cm}$ access window from the canine fossa using a circular skill saw. Bone fragment was conserved representing an important margin of the maxillary sinus.

Once access was attained we proceeded to seal the maxillary sinus ostium with dental yellow wax, sinus walls were lubricated with liquid Vaseline to ease removal of the impression. As the impression material was introduced in the maxillary sinus, the anterior margin was filled with fragment obtained as window was realized.

Silicone impression volume was measured by Arquimedes principle, also known as the fluid displacement technique. Each maxillary sinus impression was placed in $90 \mathrm{ml}$ volumetric flask in water at room temperature; water displacement from the impression shows the corresponding maxillary sinus volume.

Analysis. The estimated volume as formula was applied to groups of 3,5 and 9 slices, was compared with real volume (gold standard). With this information the error percentage by method was calculated, Pearson's correlation value and the differences of means using $t$ test with $\mathrm{p}<0.05$.

\section{RESULTS}

Method error percentage varied in 6.84 to $3.05 \%$, with an important correlation between estimated and real volume in all groups, though no statistically significant differences were found between them. Results are detailed in Table I.

\section{DISCUSSION}

We present a method to estimate maxillary sinus volume starting with groups of 3,5 and 9 coronal slices by TC applying the combined Cavalieri method with systematic and randomized sampling of images studied. Volume estimated presented high correlation with real volume, with no differences noted between groups. This method was previously described for orbit volume with similar results (Coronado et al., 2010). 
Table I. Descriptive and analytical statistical data of real and estimated volumes beginning with sequence of groups of 3 , 5 and 9 slices.

\begin{tabular}{lccccccc}
\hline Right Maxillary Sinus & Minimum Maximum & Mean & SD & Error*\% & $\begin{array}{c}\text { Significant } \\
\mathbf{P}<\mathbf{0 , 0 5}\end{array}$ & Correlation $^{* * * *}$ \\
\hline Real Volume & 8.00 & 23.00 & 13.90 & 4.62 & & & .973 \\
Volume meas ured in 3 slices & 8.70 & 25.30 & 14.25 & 5.23 & 2.56 & No & .958 \\
Volume meas ured in 5 slices & 9.38 & 23.90 & 14.85 & 4.80 & 6.84 & No & .965 \\
Volume meas ured in 9 slices & 9.17 & 24.40 & 14.46 & 5.07 & 4.02 & No & \\
Left Maxillary Sinus & & & & & & & .927 \\
Real Volume & 8.00 & 21.00 & 14.00 & 3.80 & & No \\
Volume measured in 3 slices & 8.50 & 21.10 & 13.60 & 3.90 & -2.81 & No & .894 \\
Volume meas ured in 5 slices & 9.80 & 22.30 & 14.27 & 4.03 & 1.97 & No & .900 \\
Volume meas ured in 9 slices & 8.39 & 23.90 & 13.57 & 4.91 & -3.05 & & \\
\hline
\end{tabular}

* Percentage of error in reference to the Gold Standard.

*** Statistical significance of the differences when compared to the Gold Standard with estimate using $\mathrm{t}$ test for relate samples

**** Pearson's $\mathrm{r}$ value when correlating the Gold standard value with the estimated value

There is consensus that the use of TC images allows determination of lineal dimensions and volumes. However exact determination is less in cavities that are irregular, which appears to resolve with the use of helicoidal TC and tridimensional reconstruction (Alder et al., 1995; Cavalcanti \& Vannier, 1998). The main advantage of the proposed methods is that with a limited number of slices it is possible to accomplish reliable estimates of maxillary sinus volume without the requirement of additional software or specialized equipment, thereby allowing assessment of the maxillary sinus volume particularly during procedures of sinus floor elevation for implants, evaluation of hypoplasia and symmetries in craniofacial development (Sirikei et al., 2000; Suzuki et al., 2000; Song et al. and Suo et al., 2011).

CORONADO, C.; ARRIAGADA, O. \& SUAZO, G. I. Determinación fácil y sin sesgo del volumen del seno maxilar. Int. J. Morphol., 29(4):1375-1378, 2011.

RESUMEN: La determinación del volumen del seno maxilar es necesaria en distintos procedimientos. En este estudio presentamos un método sencillo para la estimación del volumen del seno maxilar a partir de grupos de 3,5 y 9 cortes coronales obtenidos mediante TC aplicando el método de Cavalieri combinado con un muestreo sistemático y aleatorio de las imágenes evaluadas. Utilizamos 10 cráneos secos los cuales fueron sometidos a TC con cortes de $1 \mathrm{~mm}$ de espesor a partir de cuyas imágenes se seleccionaron grupos de 3, 5 y 9 cortes coronales que involucraban al seno maxilar. El volumen real se determinó utilizando silicona adaptada a la cavidad del seno maxilar. El volumen estimado presentó una alta correlación con el volumen real, no encontrándose diferencias entre los grupos. Se concluye que es posible la estimación sin sesgo y con una elevada exactitud del volumen del seno maxilar a partir de un mínimo de 3 imágenes de TC obtenidas mediante muestreo sistemático y aleatorio con el método propuesto.

PALABRAS CLAVE: Principio de Cavalieri; Volumen; Tomografía Computada; Seno Maxilar.

\section{REFERENCES}

Alder, M. E.; Deahl, T. \& Matteson, S. R. Clinical usefulness of two-dimensional reformatted and three-dimensionally rendered computerized tomographic images: literature review had a survey of surgeons' opinions. J. Oral Maxillofac. Surg., 53:37586, 1995.

Cavalcanti, M. G. P. \& Vannier, M. W. Quantitative analysis of spiral computed tomography for craniofacial clinical applications. Dentomaxillofac. Radiol.,; 27:344-50, 1998.

Cho, S. H.; Kim, T. H.; Kim, K. R.; Lee, J. M.; Lee, D. K.; Kim, J. H.; Im, J. J.; Park, C. J. \& Hwang, K. G. Factors for maxillary sinus volume and craniofacial anatomical features in adults with chronic rhinosinusitis. Arch. Otolaryngol. Head Neck Surg., 136:610-5, 2010.

Coronado, C.; Arriagada, O.; Zavando, D.; del Sol, M. \& Suazo, G.I.C. Estimación del Volumen Orbitario Mediante Imágenes de TC y el Principio de Cavalieri. Rev. Chil. Radiol., 16(2):5963, 2010. 
Deeb, R.; Malani, P. N.; Gil, B.; Jafari-Khouzani, K.; SoltanianZadeh, H.; Patel, S. \& Zacharek, M. A. Three-dimensional volumetric measurements and analysis of the maxillary sinus. Am. J. Rhinol. Allergy, 25:152-6, 2011.

Gray, C. F.; Staff, R. T.; Redpath, T. W.; Needham, G. \& Renny, N. M. Assessment of maxillary sinus volume for the sinus lift operation by three-dimensional magnetic resonance imaging. Dentomaxillofac. Radiol., 29:154-8, 2000.

Kuhl, S.; Gotz, H.; Hansen, T.; Kreisler, M.; Behneke, A.; Heil, U.; Duschner, H. \& d'Hoedt, B. Three-dimensional analysis of bone formation after maxillary sinus augmentation by means of microcomputed tomography: a pilot study. Int. J. Oral Maxillofac. Implants, 25:930-8, 2010.

Park, Y. B.; Jeon, H. S.; Shim, J. S.; Lee, K. W. \& Moon, H. S. Analysis of the anatomy of the maxillary sinus septum using 3-dimensional computed tomography. J. Oral Maxillofac. Surg., 69:1070-8, 2011.

Perella, A.; Rocha, S. dos S. \& Cavalcanti, M. de G. Quantitative analyses of maxillary sinus using computed tomography. $J$. Appl. Oral Sci., 11:229-33, 2003.

Perrella, A.; Albuquerque, M. A.; Antunes, J. L. \& Cavalcanti, M. G. Volumetric and linear assessment of maxillary sinuses using computed tomography. Bull. Group Int. Rech. Sci. Stomatol. Odontol., 46:8-14, 2004.

Sirikci, A.; Bayazit, Y.; Gumusburun, E.; Bayram, M. \& Kanlikana, M. A new approach to the classification of maxillary sinus hypoplasia with relevant clinical implications. Surg. Radiol. Anat., 22:243-7, 2000.

Song, S. Y.; Hong, J. W.; Roh, T. S.; Kim, Y. O.; Kim, D. W. \& Park, B. Y. Volume and distances of the maxillary sinus in craniofacial deformities with midfacial hypoplasia. Otolaryngol. Head Neck Surg., 141:614-20, 2009.

Suo, W. C.; Gu, Z. Y.; Ruan, H.; Guo, X. H.; Zhang, W. B. \& Shi, H. M. Measurement of the height and width of residual alveolar crests in low-set maxillary sinus patients with missing upper molar. Shanghai Kou Qiang Yi Xue, 20:308-13, 2011.

Suzuki, H.; Yamaguchi, T. \& Furukawa, M. Maxillary sinus development and sinusitis in patients with cleft lip and palate. Auris Nasus Larynx, 27:253-6, 2000.

\author{
Dirección para correspondencia: \\ Dr. César Coronado Gallardo \\ Av. Pedro de Valdivia 1161, Casilla 3457 \\ Concepción, \\ CHILE
}

E-mail: ccoronado.gallardo@gmail.com

Recibido : 02-08-2011

Aceptado: 02-09-2011 